\title{
STOCK ASSESSMENT AND FISHERY MANAGEMENT OF THE PINK SHRIMP Farfantepenaeus brasiliensis LATREILLE, 1970 AND F. paulensis PÉREZ-FARFANTE, 1967 IN SOUTHEASTERN BRAZIL $\left(23^{\circ}\right.$ TO $\left.28^{\circ} \mathrm{S}\right)$
}

\author{
LEITE JR., N. O. ${ }^{1}$ and PETRERE JR., M. ${ }^{2}$ \\ ${ }^{1}$ Projeto TAMAR, Av. Paulino Mueller, 1111, Jucutucuara, CEP 29040-715, Vitória, ES, Brazil \\ ${ }^{2}$ Departamento de Ecologia, UNESP, Av. 24-A, 1515, Bela Vista, C. P. 199, CEP 13506-900, Rio Claro, SP, Brazil \\ Correspondence to: Nilamon de Oliveira Leite Júnior, Projeto TAMAR, Av. Paulino Mueller, 1111, Jucutucuara, \\ CEP 29040-715, Vitória, ES, Brazil, e-mail: nilamon@tamar.org.br
}

Received June 25, 2004 - Accepted August 16, 2004 - Distributed February 28, 2006

(With 5 figures)

\begin{abstract}
Quantitative analyses of the pink shrimp (Farfantepenaeus brasiliensis and Farfantepenaeus paulensis) fisheries were carried out using data collected from July 1999 to July 2001 from the trawling operations of the fishing fleet based in Santos/Guarujá, SP. According to classical models, the fishery is at its maximum sustainable yield. Therefore, reduction of the fishing effort and adequate season and area closures seem to be the best management actions for the pink shrimp fishery.
\end{abstract}

Keywords: tropical commercial marine fisheries, pink shrimp, Farfantepenaeus, stock assessment, Brazil.

\section{RESUMO}

\section{Avaliação de estoques e manejo pesqueiro do camarão-rosa Farfantepenaeus brasiliensis Latreille, 1970 e F. paulensis Pérez-Farfante, 1967 no Sudeste do Brasil $\left(23^{\circ}-28^{\circ} \mathrm{S}\right)$}

Análises quantitativas do camarão-rosa (Farfantepenaeus brasiliensis e Farfantepenaeus paulensis) foram realizadas com dados coletados de Julho/1999 a Julho/2001, da frota de arrasto sediada em Santos/Guarujá (SP). De acordo com os modelos clássicos de manejo, a pescaria atingiu seu rendimento máximo sustentável. Assim, uma redução no esforço pesqueiro, combinada com a adoção de defesos periódicos e o fechamento de algumas áreas à pesca, parecem ser as melhores medidas de manejo do estoque para o camarão-rosa.

Palavras-chave: pescarias industriais tropicais marinhas, camarão-rosa, Farfantepenaeus, avaliação de estoques, Brasil.

\section{INTRODUCTION}

\section{Fishery history}

Exploitation of shrimps of the family Penaeidae is a long-standing and widespread activity in many subtropical and tropical areas of the world, especially in coastal areas of several countries (Garcia \& Le Reste, 1986).

From the 1950s on, shrimp exploitation increased dramatically due to the development of a specialized industrial fishery. This increase was first observed in the Gulf of Mexico and expanded rapidly throughout several countries in South America, Africa and Oceania. At the end of the 1970s, the international market became highly favorable to the commercialization of this resource, mostly because of high market prices and an increase in the demand by developed countries (e.g., USA, Europe and Japan). Owing to this demand, the world production of shrimps from the 
family Penaeidae reached 700 thousand tons in the early 1980s (Isaac et al., 1992).

As a result of this increase, combined with a lack of basic biological information, most of the world's shrimp stocks are now highly or completely exploited, and many species can even be considered over-exploited. Owing to the paucity of basic knowledge about the population dynamics of the most exploited species, any effort towards a rational and well ordered exploitation of the stocks is a difficult task (Garcia \& Le Reste, 1986; Isaac et al., 1992).

The beginnings of small-scale shrimp fishery in Brazil's southeast and south is uncertain. The first available data on production rates date from 1945 for the state of Rio Grande do Sul. The small-scale fishery focuses basically on juvenile shrimps in coastal and estuarine areas, which are known to serve as nurseries for the species. The fishing gear utilized varies from one area to another. For example, fishery in southeastern Brazil involves the use of gear such as cast nets, trawl nets, and trawling by two rowing canoes, while in southern Brazil, besides the two aforementioned methods, "aviãzinho", "saco" and "coca" type nets are also commonly employed (Valentini et al., 1991).

Industrial fishing in Brazil took off after World War II with the mechanization of the São Paulo and Rio de Janeiro fishing fleets. The most commonly used gear is the double otter trawl, using wooden or steel boats equipped with lateral masts called tangones, which allow for the simultaneous operation of two twin nets (Mexican method) and sometimes a third, smaller probe net to pre-evaluate the size of the catch (Iwai, 1973; Vendeville, 1990). Fishing is carried out at night, when the yield of the trawlers is higher due to the nocturnal habits of this species. During the day, individuals of this species bury themselves in the substratum. Nevertheless, occasionally catches also occur during the day, using "frighteners" to flush the shrimps out of hiding.

The trawling fleets basically operate on the adult stock in the open sea, ranging from Brazil's northern coast down to the state of Santa Catarina in the south. The history of Brazil's modern-day fishing industry has been marked by several eventful changes, including the replacement of cotton nets for synthetic nets in 1965, the introduction of double nets in the fishing fleets of Rio de Janeiro and São
Paulo states, the beginning of industrial fishing in the state of Santa Catarina in 1968; exploitation of the shrimp stocks of the states of Espírito Santo and southern Bahia in 1970, and the experiments with twin net systems in Santa Catarina in 1986 (Valentini et al., 1991).

Today the exploitation of pink shrimps in southern and southeastern Brazil is stable, with a fleet of almost 400 trawlers officially permitted by Brazil's Federal Environmental Agency (IBAMA) to exploit this resource. The fleet operates with wooden-hulled trawlers having an average total length of $18.5 \mathrm{~m}$, average gross tonnage of $55 \mathrm{t}$ and 246 HP engines. In southeastern Brazil, the São Paulo state fleet represents $59 \%$ of the country's fishing trawlers, followed by Santa Catarina (20\%), Rio de Janeiro (18\%), Espírito Santo (3\%), and Rio Grande do Sul (0.4\%) (IBAMA, 1997).

Worldwide, Brazil ranks $12^{\text {th }}$ in terms of shrimp catches and $6^{\text {th }}$ in the catch of the family Penaeidae (FAO, 1998). Between 1984 and 1985, shrimps represented about $6 \%$ of the weight and approximately $24 \%$ of the profits deriving from the total fishery production of southeastern and southern Brazil. In 1987, pink shrimp fishery alone represented $16 \%$ of the entire shrimp catch in the area (Valentini et al., 1991).

Data garnered from 1965 to 1999 (D'Incao et al., 2002) on Brazil's pink shrimp (F. brasiliensis and $F$. paulensis) fishery in the country's southeast and south indicates that the highest total stock catch (16,028 tons) occurred in 1972 and the lowest (2,008 tons) in 1998. These values coincide with the highest and lowest values (9,832 and 570 tons), respectively, achieved by small-scale fishery in the same years. The best results obtained by industrial fishing were recorded from 1969 (7,102 tons) to 1972 (6,797 tons), probably due to the federal government's policy of fiscal incentives for the fishing industry adopted at that time. This policy strongly favored shrimp fisheries because of its high economic value and the fast return on investments resulting from a rapid growth of the export market. The total production of pink shrimp in southeastern and southern Brazil expanded up to 1972 , after which it showed a declining trend, albeit with peaks in 1979 (12,780 tons) and 1985 (12,511 tons), thereafter dropping to extremely low values in 1994, 1998 and 1999 (2,100, 2,008 and 
2,207 tons, respectively) (Valentini et al., 1991; D'Incao et al., 2002).

The Permanent Shrimp Study Group (Grupo Permanente de Estudos de Camarões - GPE Camarão) has made several assessments of the shrimp stock of southeastern and southern Brazil. In 1984, the existing fishery data were divided into two periods: the first from 1965 to 1972 and the second starting in 1973. From 1992 to 1994, a group of specialists attending technical meetings promoted by IBAMA reorganized the historical shrimp production data, dividing them into three periods: a) $1965-1972$, b) $1973-1986$, and c) $1987-$ 1994. The reason behind this reorganization was the discovery that the intensive exploitation of the stock had led to a break in the original stock balance, which settled to a lower level. An analysis of the historical data on industrial fishing yield from 1965 to 1994 shows a gradual increase up to 1969 , with a production of 7,102 tons. This upward trend in yields was followed by a decline until 1973, when the catch was down to 2,283 tons. From 1974 to 1994 , industrial fishing yields varied from 3,600 tons in 1984 to 1,476 tons in 1994 (Valentini et al., 1991; IBAMA, 1997). This period was followed by a abrupt decline to the 948 tons recorded in 1999 (D'Incao et al., 2002).

These figures clearly illustrate the sharp reduction in the abundance of industrial fishing yields, with pink shrimp fishery revealing three distinct periods, the first up to 1972, with an average CPUE (catch per unit effort) of $16.57 \mathrm{Kg} \cdot \mathrm{h}^{-1}$, the second from 1973 to 1986, with an average of 5.23 Kg.h ${ }^{-1}$, and the third from 1987 to 1995 , with an average of $3.81 \mathrm{Kg} \cdot \mathrm{h}^{-1}$ (D'Incao et al., 2002).

\section{Fishery regulation and control}

Pink shrimp fishing in southeastern and southern Brazil was officially regulated in the late 1960s. Since then, several additional measures have been adopted to limit the fleet (through the concession of special fishing permits), the size of individuals caught by small-scale fisheries, the fishing net mesh size and type of fishing gear, to delimit regulated fishing areas and, starting in 1983, introduction of the prohibition against year-round fishing and establishment of a legal fishing season starting the following year.

The current legislation for shrimp fishery in southeastern Brazil is based on two main objectives: stabilization of the fishing fleet and maintenance of a period when fishery is prohibited in order to protect the recruitment.

The ban period recommended by the GPE, which underpinned the old SUDEPE (Fishing Development Superintendence,) in the structuring of this action in 1983, was 120 days, beginning on February 1 and ending on May 31, when recruitment of the pink shrimp occurs. However, several actions by SUDEPE, which resulted in the relaxation of the prohibition in some years until its complete suppression in 1988, minimized the results achieved through the initial control. The ban for 2001 was established from March 1 to May 31 (Government Directive 074/2001 IBAMA/MMA).

In recent years, the species' productivity and abundance has been higher than during the years preceding the adoption of the ban. However, these improved conditions have led to the addition of new fishing boats, with and without permits, to the fleet, resulting in the increased exploitation of the resource. Thus, the interdiction has not led to a reduction in the fishing effort, as originally intended (SUDEPE/PDP, 1988; Isaac et al., 1992; Valentini et al., 1991; IBAMA, 1991; 1993; 1997).

Because of the economic importance of the pink shrimp fishery in southeastern and southern Brazil, and due to the steadily declining yield year after year despite the adoption of controlling actions, efforts are required to study the population dynamics of this resource, allowing for the evaluation and definition of the extent to which current management actions effectively preserve this resource.

Most of the studies carried out to date on the pink shrimp of southeastern and southern Brazil investigated the two species, Farfantepenaeus brasiliensis and $F$. paulensis, in tandem. This may lead to misleading conclusions about the stocks since, despite their similar habits, these species show subtle and important biological differences (Valentini et al., 1991; IBAMA, 1991; 1993; 1997).

As mentioned earlier, actions aimed at managing the pink shrimp fishery are open to criticism. Although the results indicate that the ban produced reasonable results, the stocks are still over-exploited and far from a state of equilibrium; indeed, they are at serious risk of collapsing. 
This study proposed to evaluate the stocks of both pink shrimp species and identify the level of maximum sustainable fishing effort, thereby preventing a collapse while allowing for the maximization of profits. Also proposed was an analysis of the current methods used in fishery control.

\section{MATERIALS AND METHODS}

From June 1999 through June 2001, except for the months of March and April 2000 and March through May 2001 - the ban period, length measurements and data on fishery statistics were garnered at the main fish depots in the municipality of Santos. This is a coastal city in the state of São Paulo, which concentrates the highest number of landings of industrial pink shrimp fishing in southern and southeastern Brazil. This concentration is due mostly to the fact that the São Paulo trawling fleet is the only one whose target species is the pink shrimp, whereas the fleets of other states have definitely opted for multispecific industrial fishing (Perez et al., 2001).

The masters of 73 shrimpers were interviewed during 217 visits, representing an average of 11 boats per month, which resulted in the following information: the fishing area (location, depth and distance from the coast), dates at the beginning and end of the trips, as well as place of departure and landing, number of days at sea, amount and duration of the trawl, and the quantity of each catch, mollusks and shrimps, etc.

In 76 samplings collected during the period, a total of 6,861 pink shrimps of both species were individually handled in order to obtain data on the total length (Lt) and carapace length $(\mathrm{Lc})$ in millimeters, the total weight $(\mathrm{Wt})$ in grams, the sex, and the stage of female maturity of both species. The two species were differentiated by observing that F. brasiliensis has a rounded spot on the $3^{\text {rd }}$ and $4^{\text {th }}$ tergolateral plates on the abdomen (Pérez-Farfante, 1988). The total length, corresponding to the distance from the rostral extremity to the telson extremity, was measured with a special shrimp ruler graded in millimeters. Carapace length was measured with a precision caliper $(0.01 \mathrm{~mm})$ from the post-orbital angle to the dorsal posterior edge of the carapace (Isaac et al., 1992; Ruffino, 1991). Weight was quantified with a precision balance
$(0.01 \mathrm{~g})$. The length measurements were grouped into classes and the monthly frequency per class was calculated. This was done per species per sex, separately or grouped. Sexual differentiation was determined by the macroscopic observation of the presence of petasma or thelycum in males and females, respectively.

\section{Data analysis}

Parameters associated with growth, mortality and the weight-length ratios used in stock evaluation models were taken from Leite Jr. \& Petrere Jr. (submitted).

The data on the catch structure by age or length classes were analyzed based on the cohort analysis of Jones (1984) with the aid of the cohort analysis of Sparre \& Venema (1997).

The pink shrimp stocks were assessed based on the following approaches: Schaefer and Fox's global production models, Beverton \& Holt's model, the predictive cohort analysis based on the ength structure developed by Jones (1984), and Thompson \& Bell's model (Sparre \& Venema, 1997).

\section{RESULTS}

\section{Length structure cohort analysis}

A cohort analysis was carried out separately for the two species studied here. For the input values, the growth parameters used were obtained by ELEFAN-1, the estimates of natural mortality were calculated by Pauly's method (1980), and the terminal E (exploitation rate) used was 0.5.

Tables 1 and 2 list the results of the cohort analysis for the period of Jun 1999 to Dec 2000 (19 months). Columns 1 and 2 represent the length classes, column 3 shows the relative age in years for each length class, column 4 indicates the permanence time of each individual in each length class, column 5 indicates natural mortality (M), columns 6 and 14 represent, respectively, the catches by number of individuals and by weight $(\mathrm{Kg})$ during the study period, column 7 shows the number of individuals that reached each class at the beginning of the period, columns 8,9 and 10 show, respectively, exploitation rates (E), fishing mortality (F) and total mortality (Z), column 11 represents the average weight $(\mathrm{Kg})$ of each length class, 


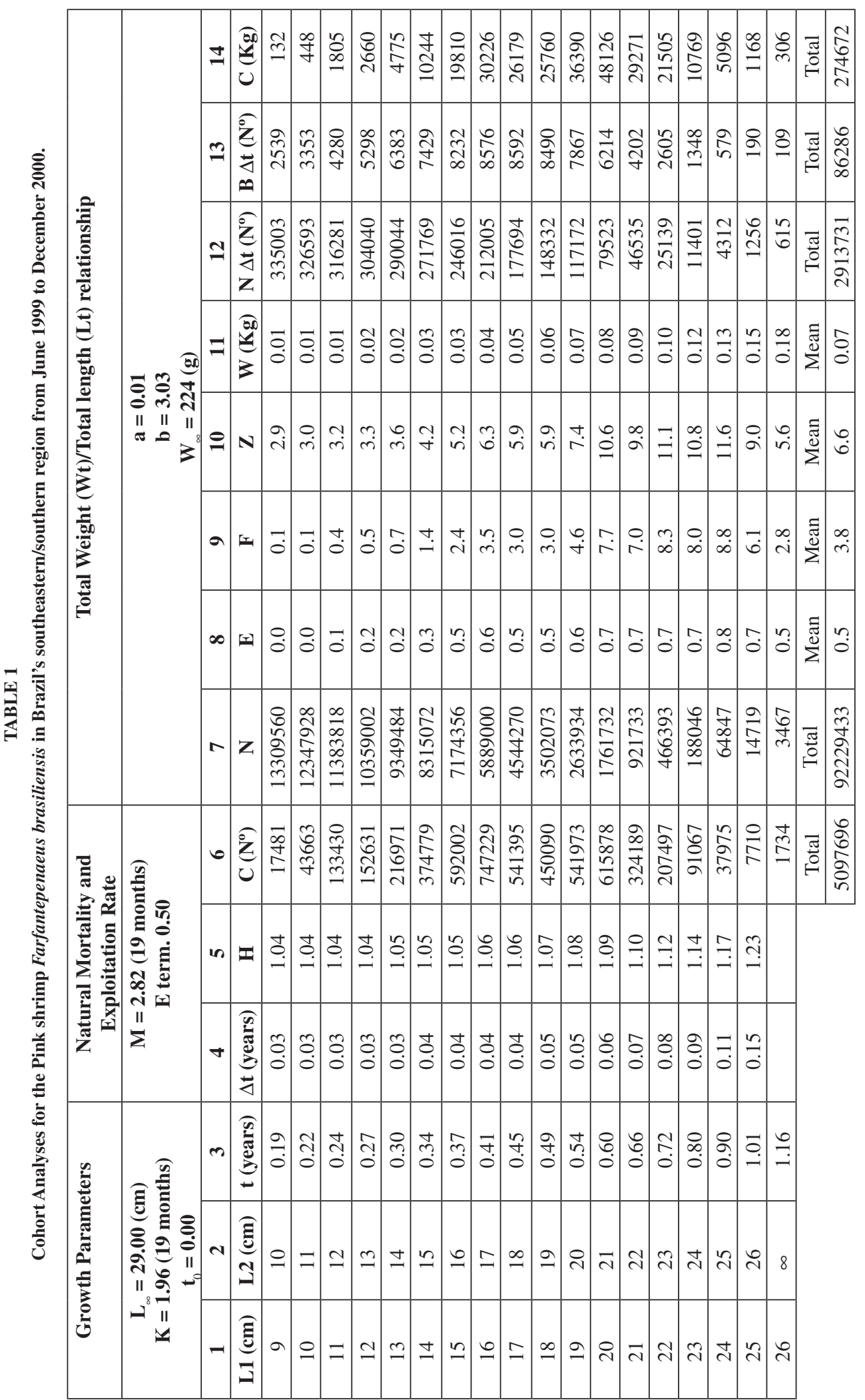




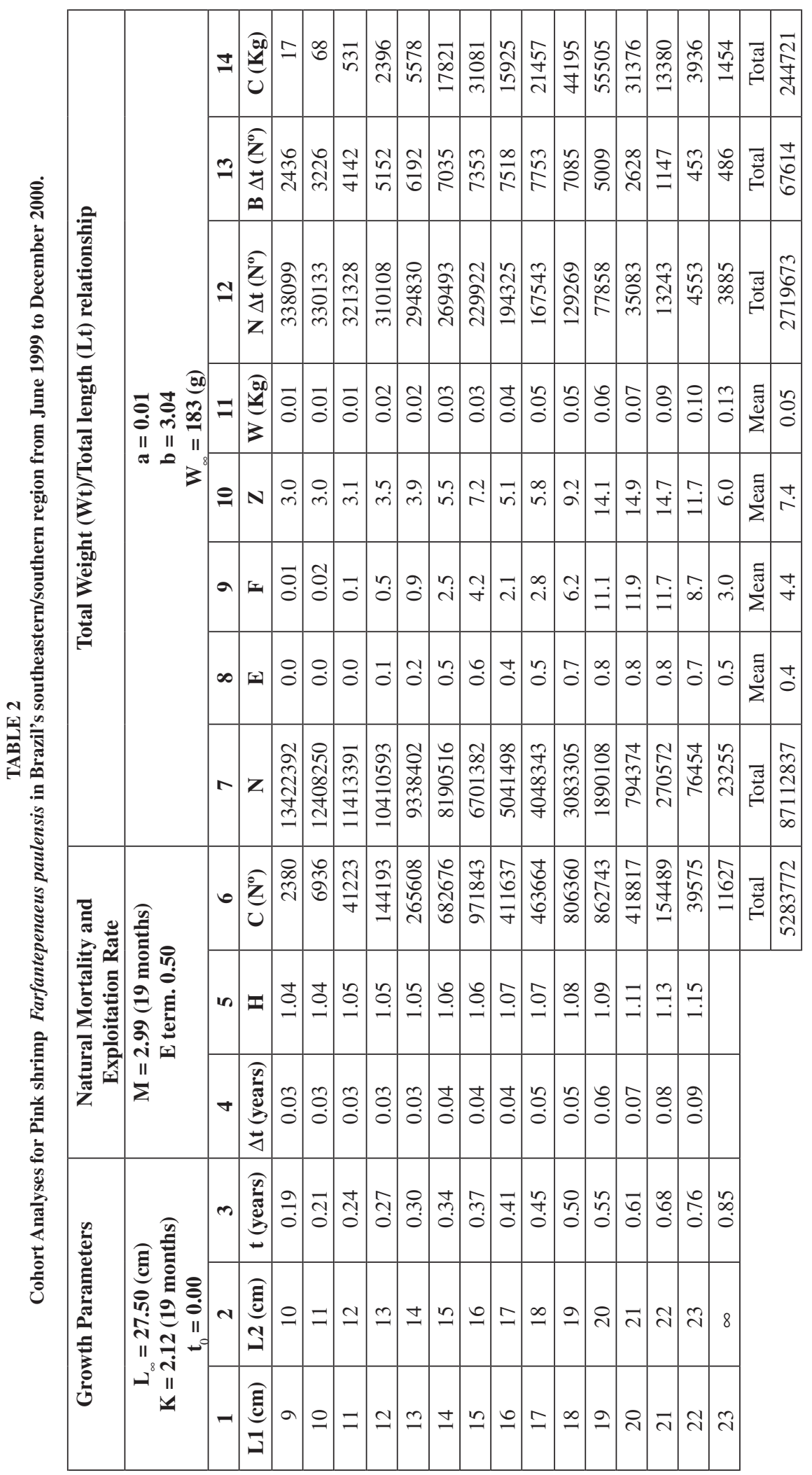


and columns 12 and 13 represent, respectively, the instantaneous stock biomass in number of individuals and in weight $(\mathrm{Kg})$ during the period. The mean biomass in the period (19 months) was 86 tons $(2,913,731$ individuals) of $F$. brasiliensis and 68 tons $(2,719,673$ individuals $)$ of $F$. paulensis.

In addition, the cohort analysis gives estimates of $\mathrm{Z}$ and $\mathrm{F}$ per length class for the period. For F. brasiliensis, the estimates of $\mathrm{Z}$, converted to annual values, increased with length and varied from 1.8 year $^{-1}$ to 7.3 year $^{-1}$, with an average of 4.2 year $^{-1}$. For $F$. paulensis, the $\mathrm{Z}$ estimates varied from 1.9 to 9.4 year $^{-1}$, with an average of 4.7 year $^{-1}$. The $F$ values also increased with length for $F$. brasiliensis, varying from 0.06 year $^{-1}$ to 5.5 year $^{-1}$, with an average of 2.4 year $^{-1}$. For F. paulensis, the $\mathrm{F}$ values varied from 0.006 year ${ }^{-1}$ to 7.5 year $^{-1}$, with an average of 2.8 year $^{-1}$.

\section{Schaefer and Fox global production models}

The data of the total catch of the industrial fleet (1995 to 2000) and the pink shrimp fishery alone (1996 to 1999) were analyzed (Fig. 1). The 1995 and 2000 data on the pink shrimp catch were excluded from the analysis because they did not fit the regression model. Table 3 presents the results of the Maximum Sustainable Yield (MSY) and Maximum Effort $\left(\mathrm{f}_{\mathrm{MSY}}\right)$.

\section{Beverton \& Holt model}

The growth parameters used as inputs for the model were obtained through the ELEFAN-1 (electronic length frequency analysis) method. Figs 2 and 3 depict the yield per recruit curves, expressed as the percentage of maximum biomass obtained for different values of $\mathrm{F}$ and Lc (length at first capture) for the species.

\section{Cohort analysis based on length structure}

The results obtained from this procedure were based on a cohort analysis of the Jun 1999 to Dec 2000 period. The model was elaborated based on hypothetical changes in the fishing effort, with situations ranging from no effort to $100 \%$ increase in effort. Fig. 4 illustrates the catch and economic yield curves obtained from the different effort values. The points in the curve represent the maximum points for catches and yield. The maximum catch of both species occurred when the actual effort was increased by $20 \%$. The economic yield curves indicate that the current fleet already operates at its maximal yield.

The monetary values of the catch (price per $\mathrm{Kg}$ of shrimp) used in both projection models were $\mathrm{R} \$ 11,00$ for individuals of up to $15 \mathrm{~cm}, \mathrm{R} \$ 22,50$ for individuals of up to $17 \mathrm{~cm}$ and $\mathrm{R} \$ 23,50$ for individuals longer than $17 \mathrm{~cm}$. These average prices were obtained from the fleet owners and represent the average prices paid to the boat masters for the three size categories (small, medium and big shrimps). The limit lengths were obtained from samplings done after the shrimps were separated at the fisheries' facilities.

\section{Thompson \& Bell model}

The input data for this model were also based in the cohort analysis, but with the modifications proposed by Sparre \& Venema (1997).

Again we worked with hypothetical changes in the fishing effort, from zero effort to a $100 \%$ increase in the effort. Fig. 5 shows the catch curves, economic yield and biomass of the stock obtained with the values modified from the current effort. The points in the curve represent the maximum points for catches and yield. The results obtained

TABLE 3

Schaefer and Fox Yield Model results for Pink Shrimp data from Brazil's southeastern/southern regions.

\begin{tabular}{|c|c|c|c|c|}
\hline Data & Method & MSY (Kg) & $\mathbf{f}_{\mathrm{MSY}}(\mathbf{h})$ & $\mathbf{Y} / \mathbf{f}_{\mathrm{MSY}}(\mathrm{Kg} / \mathbf{h})$ \\
\hline Pink-Shrimp (1996-1999) & Schaefer (1984) & 366331 & 249120 & 1.47 \\
\hline Pink-Shrimp (1996-1999) & Fox (1970) & 355699 & 266667 & 1.33 \\
\hline Total Catch (1995-2000) & Schaefer (1984) & 1465180 & 169716 & 8.63 \\
\hline Total Catch (1995-2000) & Fox (1970) & 1452784 & 141176 & 10.29 \\
\hline
\end{tabular}


Schaefer yield model (Pink-shrimp)

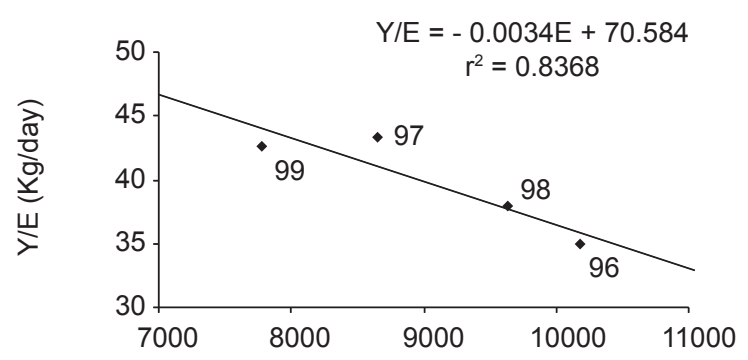

Effort (day)

(a)

Fox yield model (Pink-shrimp)

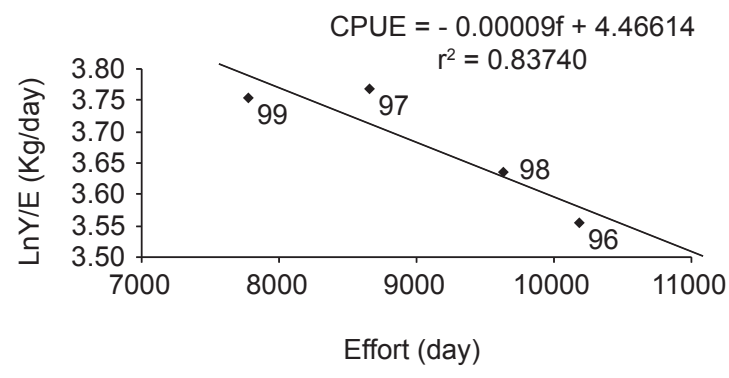

(c)

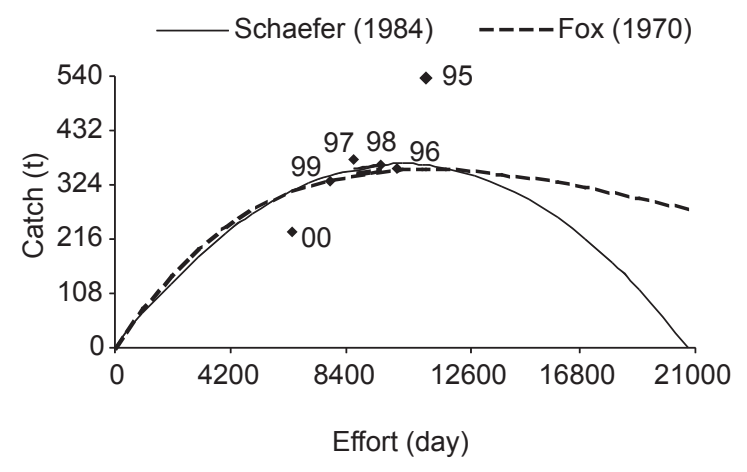

(e)
Schaefer yield model (Total Catch)

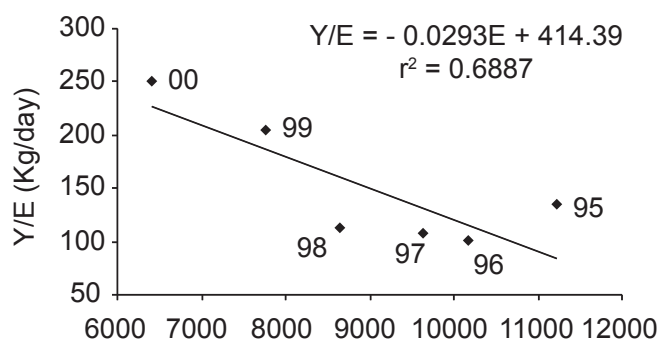

Effort (day)

(b)

Fox yield model (Total Catch)

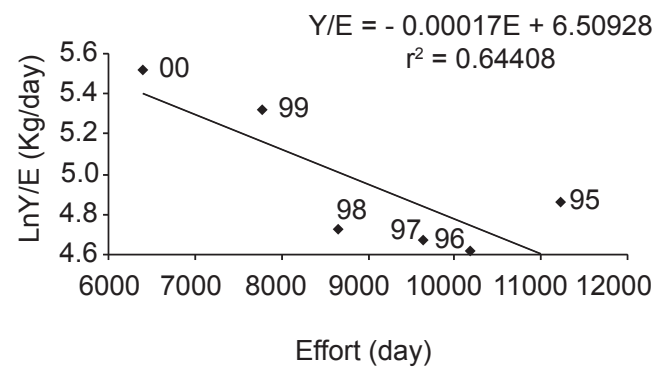

(d)

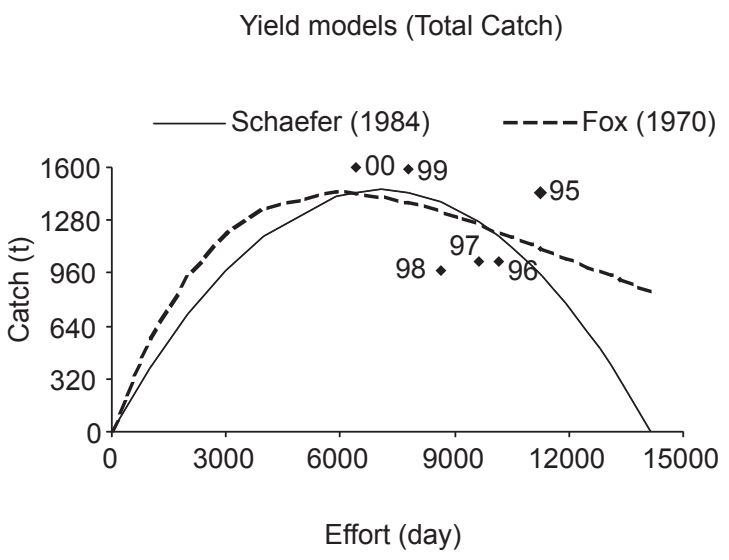

(f)

Fig. 1 - Schaefer and Fox Yield Models for Pink Shrimp data in Brazil's southeastern/southern region. 
with this model corroborate the results obtained through the predictive cohort analysis.

\section{DISCUSSION}

\section{Stock assessment}

\section{The Jones cohort analysis}

The VPA (virtual population analysis) method allows for a retroactive calculation of how many individuals were expected to be in the sea for a given catch, taking into account natural and fishing mortalities. The method assumes the existence of a stable age structure in the population, i.e., the growth parameters remain constant along the years, and differences in the individuals lengths can only be explained by age differences. To circumvent this assumption, it is advisable to use production data from several years, thus simulating a balanced situation and compensating for the differences among years in the recruitment and abundance of each class (Isaac et al., 1992; Jones, 1984).

Although we had access to the data on the fleet's total catch from 1995 to 2000, we were only able to use the data from 2 years. Thus, in this 6-year period, the sampling period for the length distribution frequency was only 19 months (Jun 1999 to Dec 2000). The data obtained in the studies of cohort analysis were used as guidelines for the projection models.

\section{Schaefer and Fox production models}

The results of the production models indicated that pink shrimp catches have been declining steadily since 1995 , when the catch was 535 tons, to 228 tons recorded for 2000. The fleet's total catches were 1450 tons in 1995, 978 tons in 1997 and 1599 tons in 2000. This reduction was a response to the decline of the target resource, which led the fleet to exploit other resources such as demersal fishes, mollusks and other crustaceans. The effort levels also diminished along the years, from 11,235 days at sea $(269,640 \mathrm{~h})$ in 1995 to 6,399 days (153,576 h) in 2000 (Fig.1).

Based on industrial pink shrimp fishery data for the southeastern and southern regions covering three different periods of fishing activity, D'Incao et al. (2002) obtained MSY values of 7165 tons and $\mathrm{f}_{\mathrm{MSY}}$ of 577,035 fishing hours from 1965 to 1972, 3049 tons and 731,964 fishing hours from
1973 to 1986 , and 1963 tons and 623,522 fishing hours from 1987 to 1995 . Although the results of this study are underestimated since they involve only catch data from the fleet that lands fish in the Santos/Guarujá-SP area, we found that the tendency for decreasing catches has remained constant along the years, indicating that this resource is seriously depleted.

The values of MSY and $\mathrm{f}_{\text {MSY }}$ obtained through the models exceed the optimum level for the pink shrimp fishery. However, taking into account the total catch, the MSY is obviously below the current catch values, with effort values close to $\mathrm{f}_{\text {MSY }}$, suggesting that the fleet is operating at levels close to the maximum yield. This finding is a matter of concern, since it is advisable for fisheries to remain at levels below the maximum estimated effort, which Garcia \& Le Reste (1986) consider a precautionary strategy.

\section{Beverton \& Holt model}

The Y/R X F curves do not present a clearly domed shape (albeit always in this case with a maximum), which is a pattern common to short-lived species (Isaac et al., 1992). Based on the catch curve (Pauly, 1983), the fleet's calculated Lc value was around $19 \mathrm{~cm}$ for $F$. brasiliensis and $18 \mathrm{~cm}$ for $F$. paulensis, while the values of $\mathrm{F}$ were 4.7 year $^{-1}$ and 6.8 year $^{-1}$ for $F$. brasiliensis and F. paulensis, respectively. These values indicate that the Lc of both species is close to the MSY and that an increase in the mesh size would not lead to a substantial increase in the catches for any level of effort in the case of $F$. brasiliensis and only a slight increase in the catches of $F$. paulensis, with an increase of $3 \mathrm{~cm}$ in the size of first catch for levels of $\mathrm{F}$ above 5.6 year $^{-1}$.

\section{Predictive cohort analysis based on length structure and the Thompson \& Bell model}

In the projection models used in this study, we worked only with a hypothetical increase or decrease in the fishing effort. As discussed above, an increase in the mesh size used by the fleet would not only reduce the yield but would also have little effect on the structure of the catch length. It is worth mentioning that the fishing operation consists of trawling the bottom for an average time of 4.5 hours. With this protocol, larger organisms were also caught (fishes, mollusks, etc.) but the 
Beverton \& Holt yield per recruit model (F. brasiliensis)

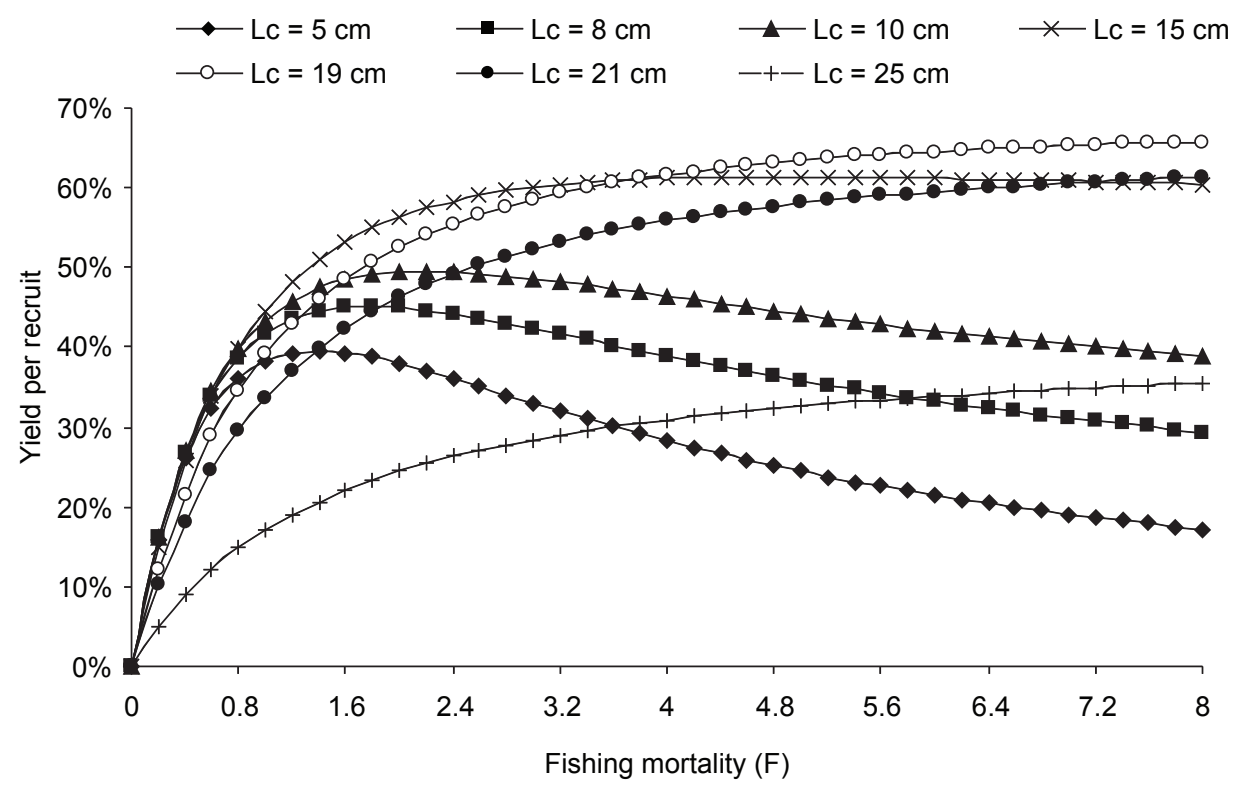

(a)

Beverton \& Holt yield per recruit model (F. paulensis)

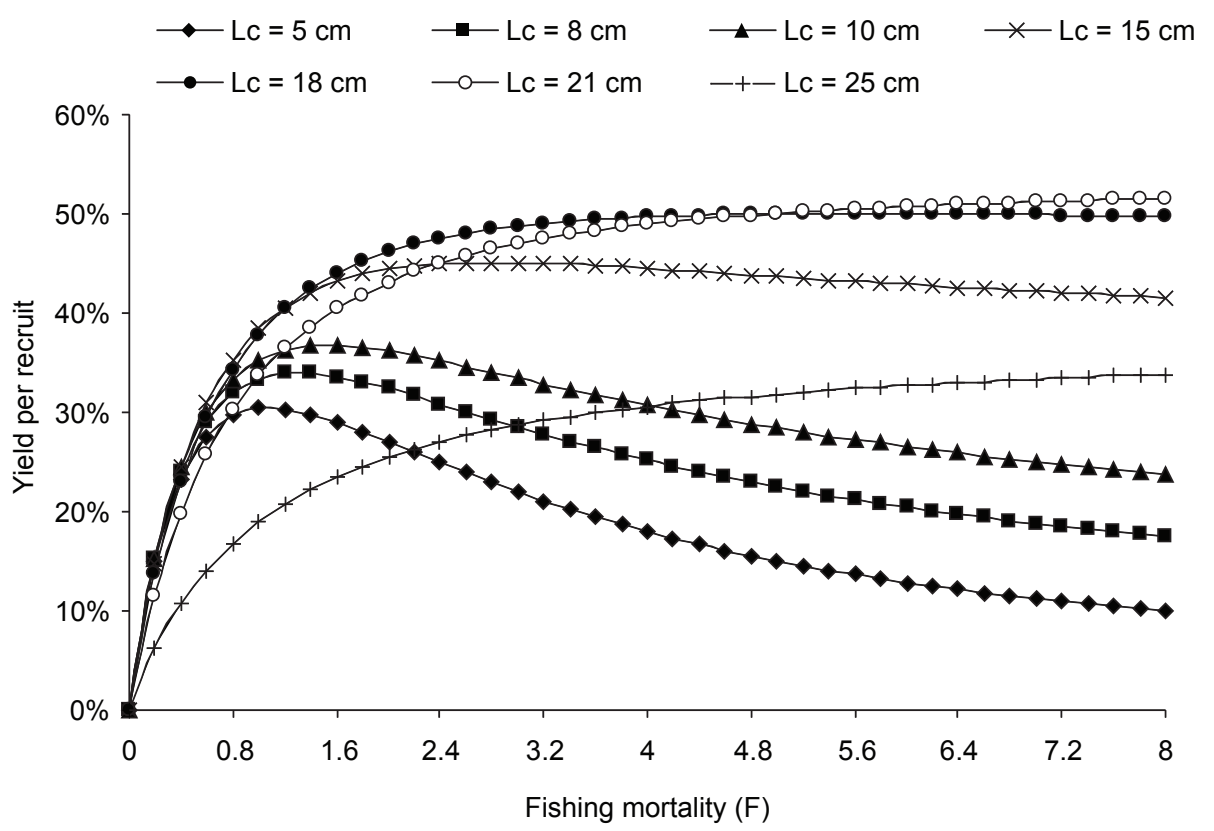

(b)

Figure 2 - Beverton \& Holt Yield per Recruit model with 7 values of first catch length, Lc, for Pink Shrimp Farfantepenaeus brasiliensis and F. paulensis. 
Beverton \& Holt yield per recruit model (F. brasiliensis)

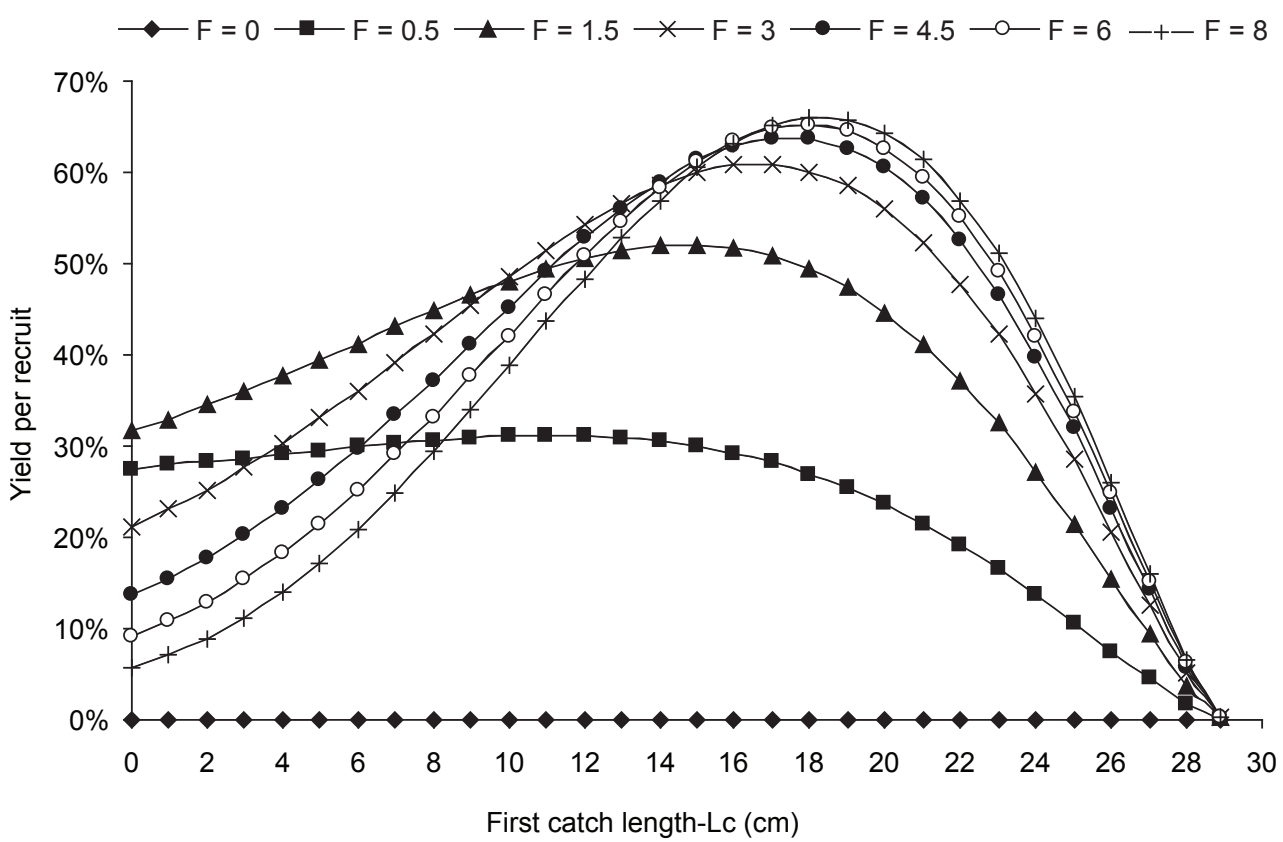

(a)

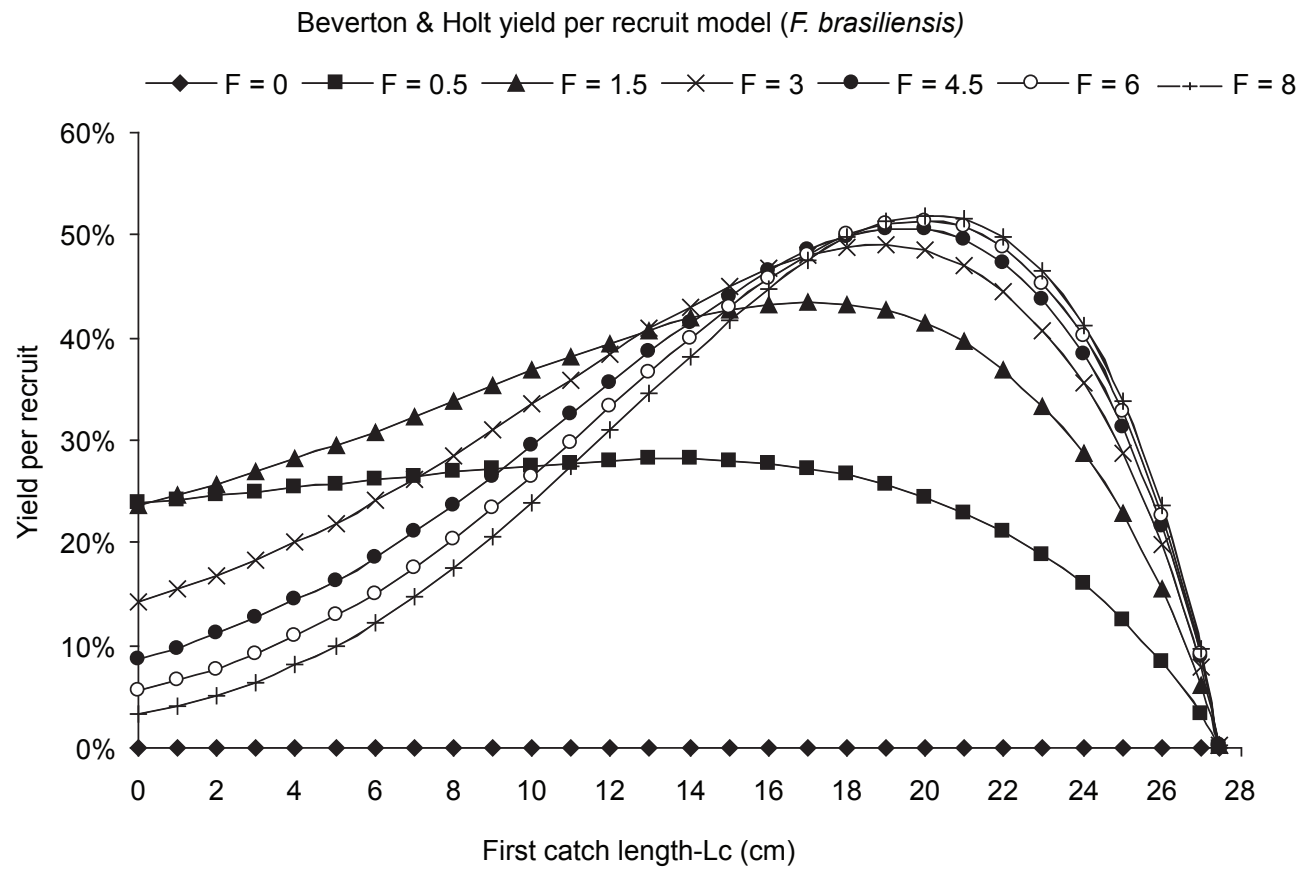

(b)

Fig. 3 - Beverton \& Holt Yield per Recruit model with 7 values of fishing mortality for Pink Shrimp Farfantepenaeus brasiliensis and F. paulensis. 


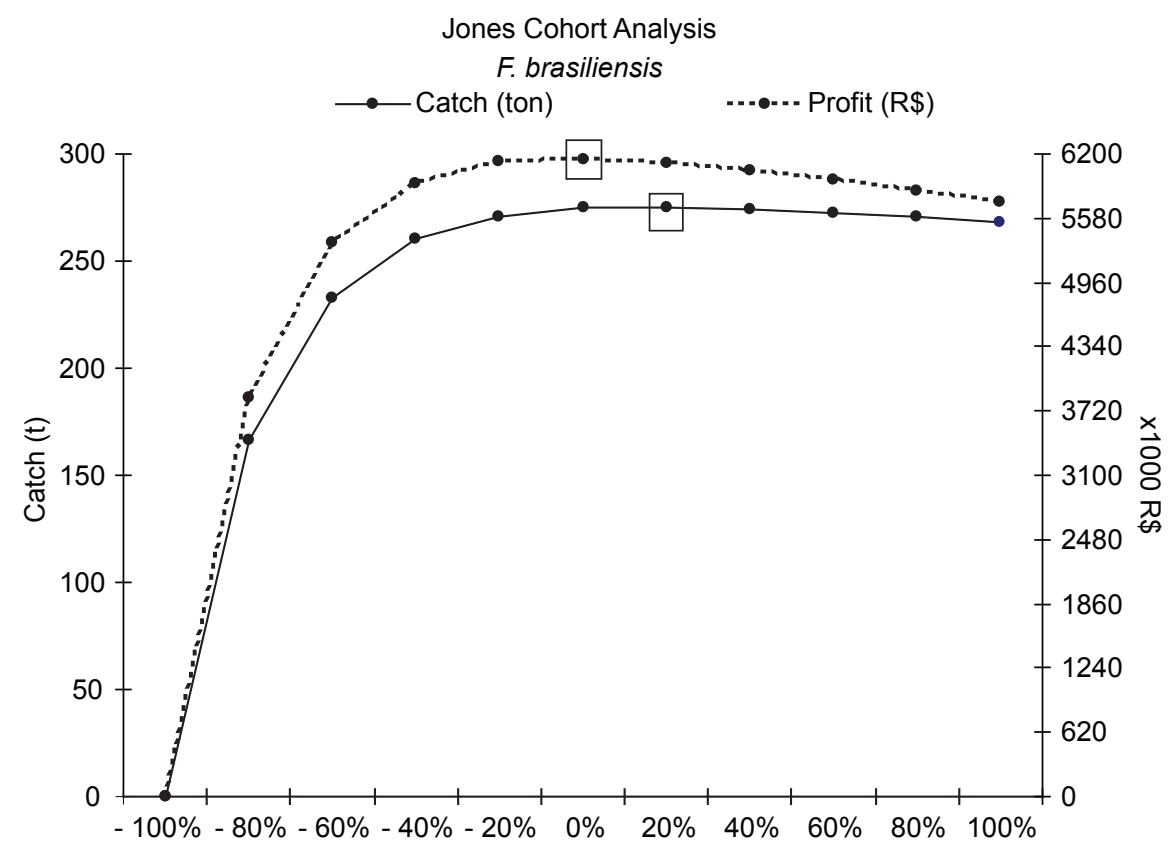

Effort increase rate

(a)

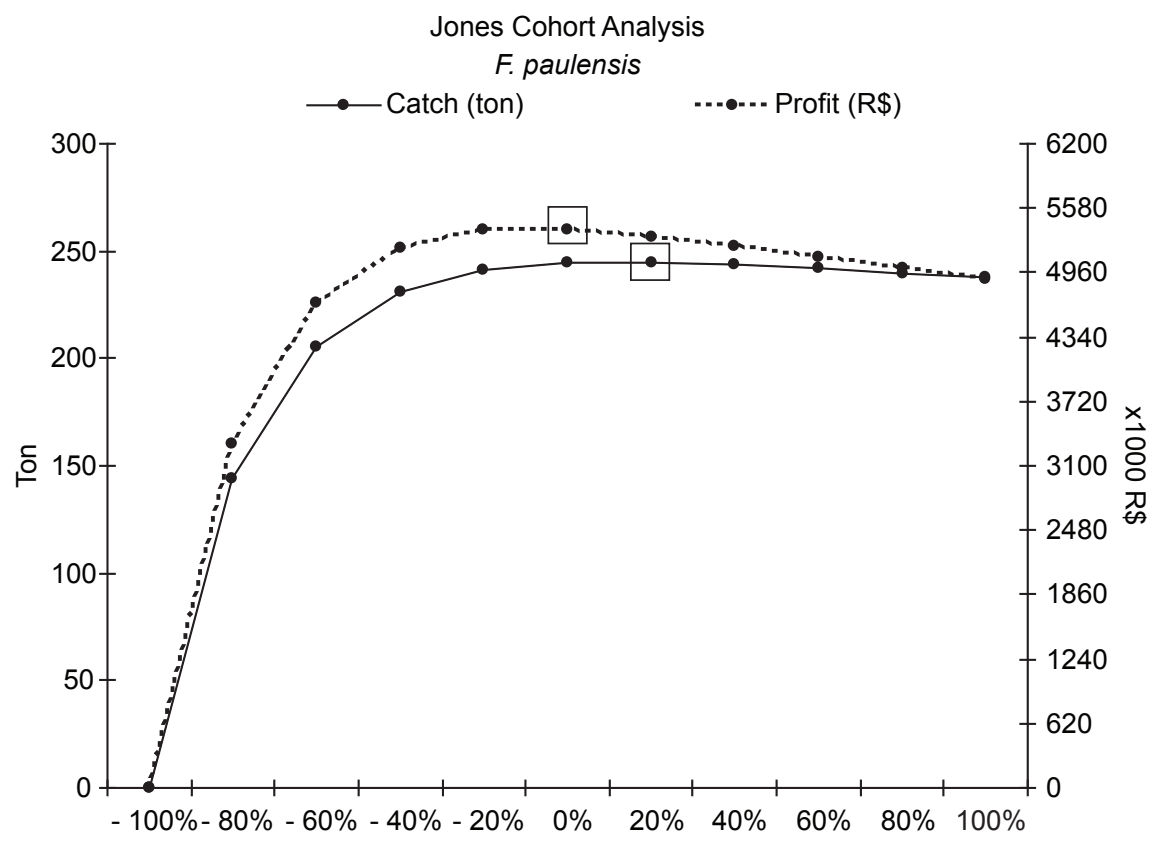

Effort increase rate

(b)

Fig. 4 - Cohort analysis for Farfantepenaeus brasiliensis and F. paulensis, from June 1999 to December 2000. 


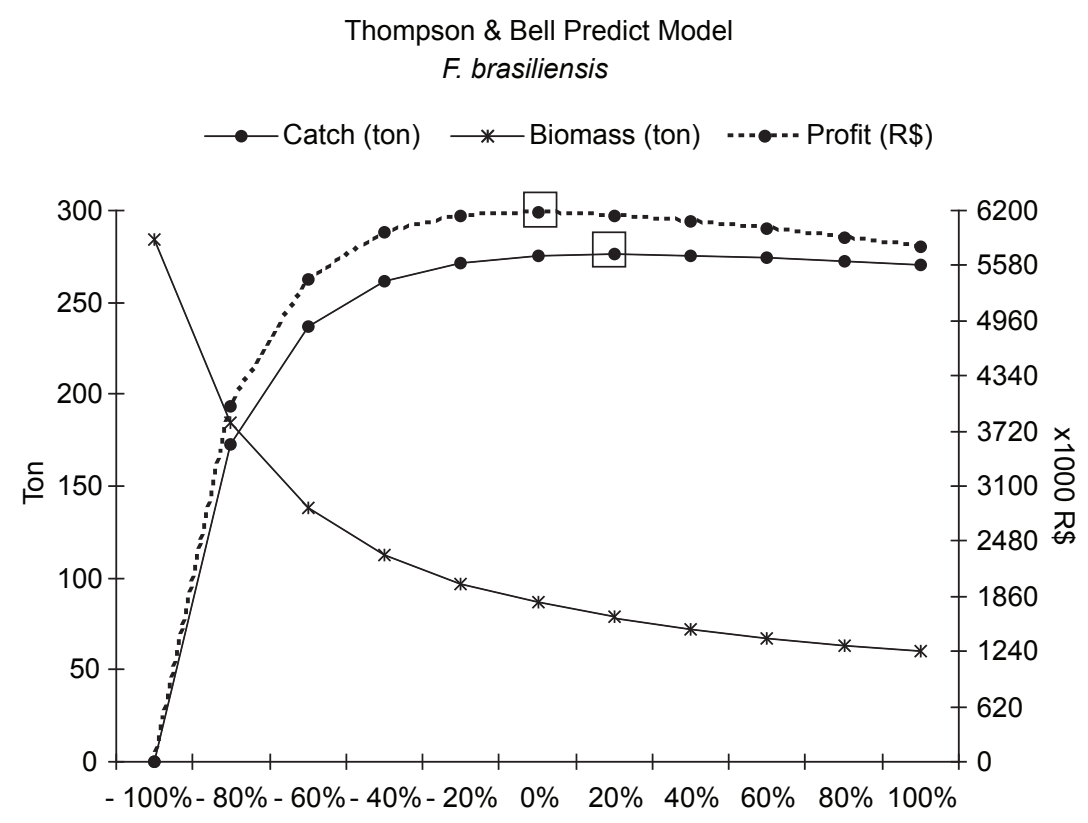

Effort increase rate

(a)

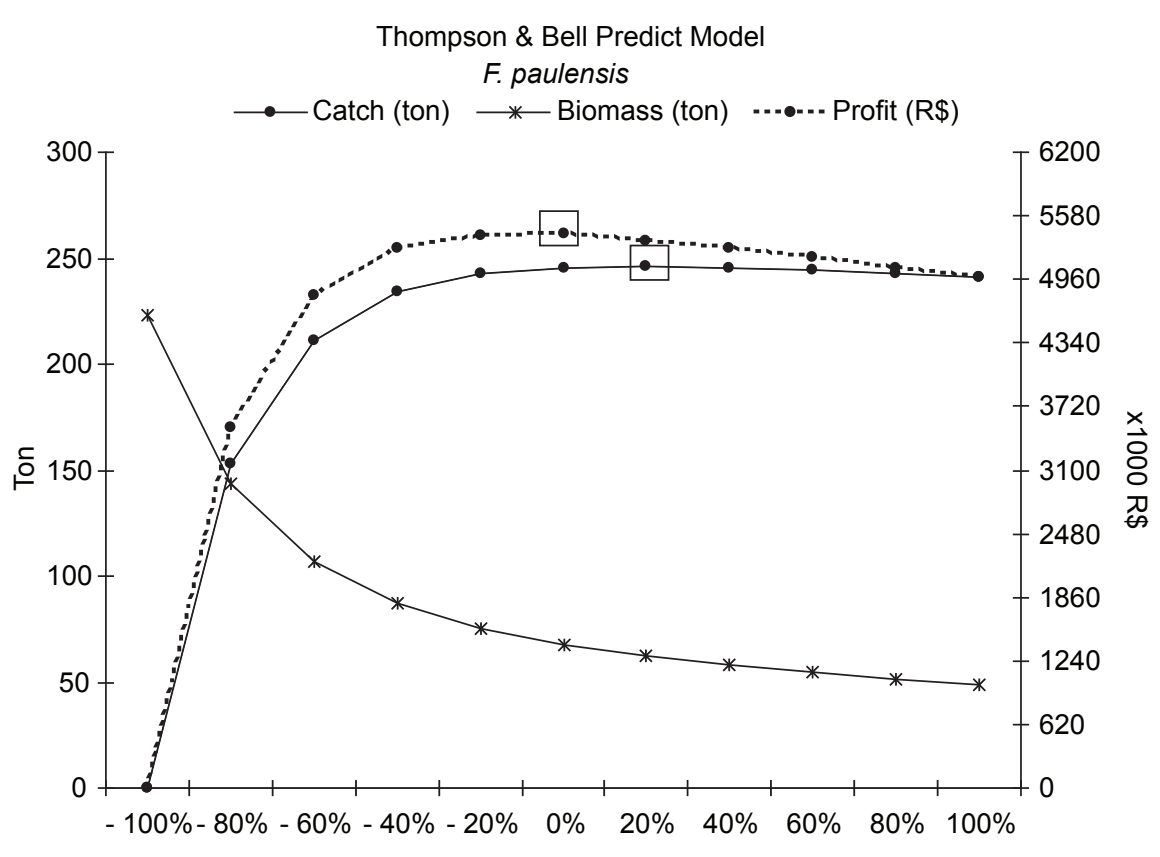

Effort increase rate

(b)

Fig. 5 - Thompson \& Bell Model for the Pink shrimp Farfantepenaeus brasiliensis and F. paulensis, from June 1999 to December 2000. Average exchange rate during the period: US\$ $1=\mathrm{R} \$ 1.924$. 
concomitant accumulation of debris soon clogged the nets.

When variations in the fishing effort were applied from zero up to a $100 \%$ increase (doubling the current effort), the models indicated that an increase in the effort caused the fish mortality and hence, the catches, to increase for the smaller length classes of both species, while decreasing the catches in the larger length classes (i.e., those of greater economic value). These results demonstrate that pink shrimp fishing has reached its peak in terms of economic yield, and that any increase in the fishing effort would lead to an increase in the proportion of smaller individuals in the catches and hence, to financial losses for the fisheries.

\section{FINAL CONSIDERATIONS}

It should be noted that this study considered only catch data relating to the industrial open sea fishery of the fleet that lands its catches in the Santos/Guarujá-SP area. Moreover, since we were unable to use the small-scale fishery data, our stock estimates are probably underestimated. Nevertheless, these estimates at least constitute good indices of stock abundance, because the São Paulo fleet represents $2 / 3$ of southeastern and southern Brazil's total active fleets (Valentini et al., 1991). All the stock evaluation models employed here indicate that the stock is at its MSY, and that urgent actions are imperative to reduce the current pink shrimp fishing effort.

\section{Fishery management}

The topics discussed here in were based mostly on data reported by Garcia \& Le Reste (1986), Isaac et al. (1992) and IBAMA (2001 - unpublished report).

Peneid shrimps are one of the world's most profitable natural resources and, as such, should be treated as a common asset of society. Moreover, because they occur in public habitats and are thus subject to free access, peneid shrimps are vulnerable to several external factors such as excessive fishing effort and environmental degradation. Since they constitute a renewable natural resource, it should be possible to exploit them widely without jeopardizing the replacement of the stock. Therefore, regulating this type of fishery right from the animals' initial phases is crucial for the optimal and profitable development of industrial pink shrimp fishing. The management of peneid shrimps involves various constraining factors, such as their high market value, short life cycle, high mortality rates, and the fact that juveniles and adults occupy different habitats. The latter factor enables different social groups (small-scale and industrial fisheries) to employ dissimilar and specialized fishing strategies for individuals of different ages. Lastly, the progressive degradation that estuarine environments (nurseries) currently face must also be considered.

The success of a fishery management policy begins with a clear definition of its objectives and the existence of an appropriate structure within which to carry out the necessary actions. According to Garcia \& Le Reste (1986), the shrimp fishery management objectives are long-term conservation of the resource, maximization of total production, catches, income and profit, reduction of production costs, improvement of the economic and social conditions of workers, with better job opportunities and redistribution of benefits, better use of the by-catch, and greater profitability for the trawlers in order to reduce juvenile fish mortality. Once these management policies have been outlined, the methods required for their implementation should be defined.

\section{CONCLUSIONS}

- Pink shrimp catches have been declining steadily since 1995 , while the total catch per fleet has increased. This decline in the catch of the target resource has prompted the fleet to exploit other resources such as demersal fishes, mollusks and other crustaceans. The levels of effort have also declined along the years, from 11235 days in 1995 to 6399 days in 2000;

- From the standpoint of the industrial fleet catch, the MSY is below the current catch values, showing effort values close to $\mathrm{F}_{\mathrm{MSY}}$, which suggests that the fleet is operating at maximum production levels. It should be noted that these calculations do not include small-scale coastal fishery landings;

- The production model indicates pink shrimp fishery is at its MSY, and that any modification 
in fishing net mesh sizes would fail to result in higher catches;

- The predictive models also indicate that the pink shrimp fishery is at its MSY. An increase in effort of up to $20 \%$ would lead to an increase in the catch. However, such an increase would lead to financial losses for the industry; and

- Since the fishery is at its maximum production level, administrative procedures must be implemented to preserve the stock. The best steps for regulating the industry are the immediate reduction of the fishing effort through a reduction of the fleet, along with the establishment of a fishing period ban and the closing of some fishing areas to ensure the recruitment of the species.

Acknowledgments - The authors acknowledge FAPESP (Process No 99/06038-0), UNESP and CNPq for their partial support of this research. We are indebted to IOUSP, UNESP (Brazil) and IP/SP for the use of their facilities and specially to Dr. Acácio Ribeiro Gomes Tomás

\section{REFERENCES}

D'INCAO, F., VALENTINI, H. \& RODRIGUES, L. F., 2002, Análise da pesca de camarões nas regiões Sudeste e Sul do Brasil. Atlântica Rio Grande, 24: 103-116.

FAO, 1998, Yearbook Fishery Statistics Capture Production, 1996, 82: 371-381.

FOX, W. W., 1970, An exponential yield model for optimizing exploited fish populations. Trans. Am. Fish. Soc. 99: 80-88.

GARCIA, S. \& LE RESTE, L., 1986, Ciclos vitales, dinámica, explotación y ordenación de las poblaciones de camarones peneidos costeros. FAO Doc. Téc. Pesca, 203, 180p.

IBAMA, 1991, Relatório da VII Reunião do Grupo Permanente de Estudos, GPE, de Camarões, Realizada no Período de 24 a 28 de Setembro de 1990 em Itajaí/SC. 40p.

IBAMA, 1993, Camarões do Sudeste e Sul do Brasil: relatório da IX reunião do grupo permanente de estudos, GPE, de camarões, realizada no período de 14 a 18 de outubro de 1991 em Itajaí/SC. Coleção Meio Ambiente, Série Estudos-Pesca, 5, 68p.

IBAMA, 1997, Diretrizes Ambientais para o Setor Pesqueiro: Diagnóstico e Diretrizes para a Pesca Marítima. Brasília: MMA. 124p.
IBAMA, 2001, Relatório da reunião técnica de ordenamento da pesca de arrasto nas regiões Sudeste e Sul do Brasil. Unpublished manuscript, 45p.

ISAAC, V. J., DIAS-NETO, J. \& DAMASCENO, F. G.,1992, Camarão-rosa da costa norte: biologia e administração pesqueira. IBAMA. Coleção Meio Ambiente, Série Estudos-Pesca 1, 187p.

IWAI, M., 1973, Pesca Exploratória e Estudo Biológico sobre o Camarão na Costa Centro-Sul do Brasil do N/O "Prof. W. Besnard" em 1969-1971. Unpublished Report, 57p.

JONES, R., 1984, Assessing the effects of changes in exploitation pattern using length composition data,with notes on VPA and cohort analysis. FAO Fisheries Technical Pape, 256, 118p.

LEITE JR., N. \& PETRERE, M., Características biológicas do camarão-rosa Farfantepenaeus brasiliensis e Farfantepenaeus paulensis capturado pela frota industrial da região de Santos/Guarujá e artesanal em Cananéia, São Paulo, Brasil. Boletim do Instituto de Pesca, SP (submitted).

PAULY, D., 1980, On the interrelationships between natural mortality, growth parameters and mean environmental temperature in 175 fish stocks. J. Cons., Cons. Int. Explor. Mer, 39: 175-192.

PAULY, D., 1983, Some simple methods for the assessment of tropical fish stocks. FAO Fish. Tech. Pap., 234, 52p.

PEREZ, J. A. A., PEZZUTO, P. R., RODRIGUES, L. F., VALENTINI, H. \& VOOREN, C. M., 2001, Relatório da reunião técnica de ordenamento da pesca de arrasto nas regiões Sudeste e Sul do Bras., 7 a 11/5/2001, CEPESUL/ IBAMA, Itajaí, SC, Unpublished Report. 45p.

PÉREZ-FARFANTE, I., 1988, Illustrated key to penaeoid shrimps of commerce in the Americas. NOAA Technical Reports NMFS, 64, 32p.

RUFFINO, M. L., 1991, Dinâmica Populacional do Camarão Artemesia longinaris Bate, 1988, Decapoda, Penaeidae, do Sul do Brasil. Dissertation, MSc, Oceaonography, Rio Grande: Fundação Universidade do Rio Grande, 96p.

SPARRE, P. \& VENEMA, S. C., 1997, Introdução à avaliação de mananciais de peixes tropicais. parte 1: manual. FAO Documento Técnico sobre as Pescas, 306/1 Rev. 2, 404p.

SUDEPE/PDP, 1988, Relatório da Reunião do Grupo Permanente de Estudos, GPE, de Camarões Sudeste/Sul, Realizada no Período de 31 de Agosto a 4 de Setembro de 1987 em Itajaí/ SC. Unpublished Report, 78p.

VALENTINI, H., D'INCAO, F., RODRIGUEZ, L. F., NETO J. E. R. \& RAHNA, E., 1991, Análise da pesca do camarão-rosa, Penaeus brasiliensis e Penaeus paulensis, nas regiões Sudeste e Sul do Brasil. Atlântica, Rio Grande 13(1): 143-157.

VENDEVILLE, P., 1990, Types of fishing gear used and their selectivity. FAO Fisheries Technical Paper, 26, 76p. 